Азаев М.Г., Османов М.М., Хаджсишалапов Г.Н.

ПРОБЛЕМЫ РАЗВИТИЯ ЖИЛИЩНОГО СТРОИТЕЛЬСТВА В РЕСПУБЛИКЕ ДАГЕСТАН НА СОВРЕМЕННОМ ЭТАПЕ

Azaev M.G., Osmanov M.M., Khadzhishalapov G.N.

\title{
PROBLEMS OF DEVELOPMENT OF HOUSING CONSTRUCTION IN THE REPUBLIC OF DAGHESTAN AT THE PRESENT STAGE
}

В статье рассматриваются цели государственной политики в жилищной сфере и жилищной обеспеченности населения Республики Дагестан, пути их реализачии и проблемы развития градострочтельства.

Ключевые слова: развитие жилищного строительства, нормативы градострочтельного проектирования.

The article discusses the aims of public policy in a housing sphere and housing material well-being of population of Republic of Daghestan, the ways of their realization and problems of town-planning.

Key words: development of town planning, norms of town-planning design.

Проблемы, препятствующие реализации комплекса мер, направленных на развитие территорий для жилищного строительства РД, заключаются в недостаточном финансовом обеспечении разработки документов территориального планирования и планировки территорий; недостаточном административном сопровождении проектов жилищного строительства; воздействии неурегулированных административных процедур, препятствующих реализации инвестиционной деятельности; нескоординированности различных государственных, муниципальных программ, программ организаций жилищно-коммунального комплекса и инвестиционных программ участников проектов жилищного строительства в своевременном обеспечении территорий инженерной, транспортной и социальной инфраструктурой. Все эти проблемы планируется разрешить в рамках реализации государственной программы Республики Дагестан «Развитие жилищного строительства в Республике Дагестан».

Программа разработана в соответствии с постановлением Правительства Республики Дагестан от 23 октября 2013 года №540 «Об утверждении порядка разработки, реализации и оценки эффективности государственных программ Республики Дагестан», Указом Президента Российской Федерации от 7 мая 2012 года №600 «О мерах по обеспечению граждан Российской Федерации доступным и комфортным жильем и повышению качества жилищно- 
коммунальных услуг», распоряжением Правительства Российской Федерации от 30 ноября 2012 года «2227-р» и приказом Госстроя от 22.05.2013 N 180/ГС «Об утверждении Методических рекомендаций по разработке региональных программ развития жилищного строительства».

Стратегической целью государственной политики в жилищной сфере на период до 2020 года является создание комфортной среды обитания человека.

Следует выделять четыре ключевых приоритета в жилищной сфере:

Первый - снижение стоимости 1 м $^{2}$ жилья, в том числе путем увеличения объемов строительства жилья экономкласса;

Второй - это развитие рынка доступного арендного жилья и некоммерческого жилья для граждан, имеющих невысокий уровень доходов;

Третий - это поддержка отдельных категорий граждан, которые нуждаются в улучшении жилищных условий, но не имеют возможности накопить средства для приобретения нового жилья;

Четвертый - совершенствование условий приобретения жилья на рынке, в том числе через механизмы ипотечного кредитования.

За последние годы объемы жилищного строительства в Республике Дагестан ежегодно наращивались. Современный уровень жилищного строительства по количеству введенного жилья в 2,45 раза превысил уровень ввода жилья в 2005 году. Ежегодно в эксплуатацию стабильно вводятся более миллиона кв. метров жилых площадей. В 2013г. введено жилья в эксплуатацию общей площадью 1536,4 тыс. м², что на 7,0\% больше, чем за соответствующий период предыдущего года. Установленное задание (1500 тыс. кв. метров) перевыполнено на 2,4 \%. Достигнутое значение показателя является наивысшим по СКФО и составляет более $40 \%$ от общего объема введенного жилья по округу.

Показатель эффективности деятельности органов исполнительной власти субъектов Российской Федерации «Удельный вес введенной общей площади жилищных домов по отношению к общей площади жилищного фонда» в Республике Дагестан в 2013г. составил 3,09 \%, что на 0,13 \% больше установленного заданием $(2,96 \%)$.

Значение удельного показателя - ввод жилья на 1 жителя, характеризующий доступность жилья, в среднем по республике составило 0,51 против 0,48 м² за 2012 год.

В среднем по республике на 1000 человек в 2013 году введено 516 м² общей площади жилья, на 6\% больше, чем в 2012году.

Обеспеченность населения жильем на 1 человека составила 17,3 м², что на 0,2 м $^{2}$ больше задания.

Создан необходимый задел на 2014 год - в стадии строительства находятся объекты жилищного назначения общей площадью около 3 млн. м², в том числе более 1 млн. м² в 328 строящихся многоквартирных жилых домах.

Мониторинг средних цен и индексов цен на первичном и вторичном рынках жилья Республики Дагестан в IV квартале 2013г. показывает стабильность цен на рынке жилья. Рост за год составил на первичном рынке $0,2 \%$, на вторичном $-5,4 \%$. 
Инвестиции в основной капитал по виду экономической деятельности «строительство» (без субъектов малого предпринимательства и параметров неформальной деятельности) составили 5,1 млрд. рублей или 29,5\% от всего объема инвестиций. За период с 2010 по 2013 год средний темп роста жилищного строительства в Республике Дагестан составил 8,8 \% в год.

Традиционно значительную долю в объемах видимого жилья в Республике Дагестан, как в сельских районах, так и городах, составляет строительство индивидуальных односемейных домов. За период с 2010 по 2013 год доля построенного индивидуального жилья в общем объеме жилищного строительства составляет около $88 \%$.

Всего по организациям различных форм собственности за счет всех источников финансирования в Республике Дагестан введено в действие жилых домов: в 2010 году $-1123,8$ в 2011 году - 1212,4 в 2012 году $-1435,9$ тыс. м ${ }^{2}$ общей площади.

Структура жилищного строительства в Республике Дагестан практически не изменилась. На рынке жилья по-прежнему отмечается дисбаланс спроса и предложения. Существенной проблемой остается несоответствие структуры спроса на жилье семей со средними и умеренными доходами (то есть доходами ниже средних, но не позволяющими гражданам быть отнесенными к категории малоимущих) и предложения жилья в среднем и нижнем ценовых сегментах, что не позволяет обеспечить доступность приобретения жилья для основной части граждан.

При имеющихся положительных сдвигах в развитии жилищного строительства, жилищная обеспеченность населения в Республике Дагестан составляет 204 единицы на 1000 человек, что более чем в 2 раза меньше среднероссийского уровня, средняя обеспеченность общей площадью жилья составляет 17,3 м $^{2}$ на человека, что на $30 \%$ меньше, чем в среднем по Российской Федерации.

Объем жилищного фонда в Республике Дагестан по состоянию на 2013 год составляет 49,7 млн. м $^{2}$, в том числе: в городских поселениях и городских округах 18,5 млн. м²; в сельской местности - 31,2 млн. м². Количество жилых единиц (квартир и индивидуальных жилых домов) составляет 600,7 тысяч (далее единицы).

Большая часть жилищного фонда характеризуется высокой степенью изноca.

Актуальность решения комплекса проблем в сфере развития жилищного строительства обусловлена тем, что приобрести жилье с использованием рыночных механизмов на сегодняшний день способен ограниченный круг семей с уровнем доходов выше среднего, что, в том числе, способствует ежегодному оттоку трудоспособного населения из РД. Это обусловлено по следующим причинам:

1. Дефицит подготовленных земельных участков;

2. Дефицит бюджетных средств на обеспечение земельных участков коммунальной инфраструктурой; 
3. Низкая доступность долгосрочных ипотечных жилищных кредитов, а также высокий уровень рисков и издержек на этом рынке.

Все мероприятия Программы направлены на развитие жилищного строительства в рамках реализации приоритетных направлений государственной политики в жилищной сфере.

Основной целью Программы является повышение доступности жилья и качества жилищного обеспечения населения, в том числе с учетом исполнения государственных обязательств по обеспечению жильем отдельных категорий граждан.

Повышение доступности жилья планируется за счет поддержки массового жилищного строительства путем:

-повышения эффективности мер градостроительного регулирования и обеспечения жилищного строительства земельными участками;

•реализации механизмов поддержки и развития жилищного строительства для целей коммерческого найма и стимулирования спроса на такое жильё;

-обеспечения строительного комплекса Республики Дагестан высококачественными конкурентоспособными, ресурсо - и энергосберегающими и доступными строительными материалами и изделиями с учетом потребностей региона и имеющихся запасов местных сырьевых ресурсов;

•исполнения государственных обязательств по обеспечению жильем отдельных льготных категорий граждан.

Программа призвана обеспечить практическую реализацию комплекса мероприятий и механизмов, направленных на создание необходимых условий для решения существующих проблем в этой сфере в рамках реализации следующих подпрограмм:

1. Развитие территорий для жнилищного строительства в «Республике Дагестан». Подпрограмма направлена на повышение доступности жилья и качества жилой среды путем создания условий по развитию территорий для жилищного строительства. В рамках подпрограммы Правительством Республики Дагестан совместно с администрациями муниципальных образований будут проводиться следующие мероприятия: вовлечение в оборот земельных участков для жилищного строительства, в том числе жилья экономкласса, разработка документов территориального планирования, в том числе проектов планировки перспективных территорий жилищного строительства; реализация мер по улучшению предпринимательского климата в сфере строительства путем уменьшения количества и сроков прохождения процедур, необходимых для получения разрешения на строительство эталонного объекта капитального строительства непроизводственного назначения, в том числе для жилья экономкласса.

2. «Стимулирование развития рынка жнилья». Подпрограмма направлена на повышение доступности жилья для населения, развитие жилищного строительства, в том числе строительства жилья экономического класса, развитие кадрового потенциала. В подпрограмму включена реализация мероприятий по содействию внедрению новых энергоэффективных и ресурсосбере- 
гающих технологий в жилищном строительстве, создание условий для строительства и реконструкции предприятий по производству строительных материалов, изделий и конструкций. А также создание сектора арендного жилья коммерческого использования в муниципальных образованиях Республики Дагестан.

3. «Оказание мер государственной поддержки в улучшении жнлищцых условий отдельнылм категориям гражсдан». Подпрограмма направлена на оказание мер государственной поддержки в улучшении жилищных условий отдельным категориям граждан, в том числе с учетом исполнения государственных обязательств по обеспечению жильем отдельных категорий граждан. В рамках подпрограммы будут реализовываться мероприятия по переселению граждан из многоквартирного жилищного фонда, признанного непригодным для проживания, аварийным, подлежащим сносу или реконструкции. Мероприятия носят социальных характер и направлены на создание органами государственной власти и органами местного самоуправления условий для осуществления гражданами права на безопасные условия проживания;

Обеспечению жильем льготных категорий граждан, состоящих на учете в качестве нуждающихся в улучшении жилищных условий;

Созданию специальных условий ипотечного жилищного кредитования отдельных категорий граждан путем субсидирования процентной ставки по кредиту, предоставления бюджетных субсидий на оплату части стоимости жилья, а также погашение ипотечного кредита, оплату первоначального взноса по ипотечному кредиту.

Для решения этих задач будет вовлечено в оборот 833 га земель федеральной собственности и 2907,5 га земель муниципальной собственности [1].

Предельный срок прохождения всех процедур, необходимых для получения разрешения на строительство эталонного объекта капитального строительства непроизводственного назначения, в том числе для жилья экономкласса будет сокращен до 130 дней.

Предельное количество процедур, необходимых для получения разрешения на строительство эталонного объекта капитального строительства непроизводственного назначения, в том числе для жилья эконом класса сократится с 40 до 15 единиц.

Необходимый объем финансирования программы составляет 4 556, 1029 тысяч рублей, в том числе за счет средств:

- республиканского бюджета -1 123, 572 тысяч рублей,

- федерального бюджета - 387, 3009 тысяч рублей,

- местных бюджетов - 1 260, 68 тысяч рублей,

- Фонда содействия реформированию жилищно-коммунального хозяйства - 1233,75 тысяч рублей.

В целях формирования комфортной среды обитания и жизнедеятельности населения в Республике Дагестан реализуется градостроительная политика, являющаяся ключевым элементом как комплексного развития территорий городских округов и поселений, так и снижения административных барьеров в жилищном строительстве. 
Состояние работ по обеспечению Республики Дагестан документами территориального планирования следующее.

В состав республики входит 42 муниципальных района, 10 городских округов, 8 городских поселений, 698 сельских поселений.

Откорректированная Схема территориального планирования Республики Дагестан утверждена постановлением Правительства Республики Дагестан от 28 августа 2013г. № 413.

Республиканские нормативы градостроительного проектирования утверждены постановлением Правительства Республики Дагестан от 22 января 2010 г. № 14 .

Разработаны и утверждены органами местного самоуправления 42 схемы территориального планирования муниципальных районов.

Разработан и утвержден генеральный план г. Хасавюрта, на стадии утверждения находятся генеральные планы городов: Дербента, Южно-Сухокумска, Буйнакска, Кизилюрта, Избербаша. Проводится работа по корректировке генеральных планов для следующих городов: Каспийск, Кизляр, Дагестанские Огни, а в городе Махачкале ведутся подготовительные работы.

Из 10 городских округов разработаны и утверждены правила землепользования и застройки в 8 городских округах.

Генеральные планы 65-ти сельских поселений разработаны и утверждены, 26-ти поселений на стадии утверждения, в 28-ми сельских поселениях проекты генеральных планов проходят процедуру публичных слушаний.

Для полного завершения подготовки генеральных планов сельских поселений в Республике Дагестан необходимо разработать генеральные планы еще 460 сельских и 8 городских поселений.

Однако, принимая во внимание невозможность финансирования муниципалитетами этих проектов полностью из своих бюджетов, начато совместное их финансирование из республиканского и местных бюджетов. Для этого Правительством РД было принято постановление от 30.07.2012г. №276, где было признано целесообразным осуществить подготовку генеральных планов поселений на условиях софинансирования [2].

В соответствии с утвержденным сетевым графиком, Министерством строительства, архитектуры и жилищно-коммунального хозяйства Республики Дагестан в 2014г. планируется разработка генеральных планов 119 сельских и городских поселений.

Для завершения разработки документов территориального планирования и градостроительного планирования муниципальных образований Республики Дагестан необходимо 465,5 млн. руб.

В целях определения мест перспективной жилой застройки подготовлен реестр земельных участков для жилищного строительства. Согласно указанному реестру площадь зарезервированных земельных участков составляет 13,4 тыс. гектаров.

Наибольшее количество перспективных земельных участков для комплексного развития территорий в целях жилищного строительства сосредоточено на территориях плоскостных муниципальных районов и городских окру- 
гов: их площади составляют 2907,47 га или 21,7 \%, на которых за период реализации программы планируется построить 1461,39 тыс. м² многоэтажного и 3506,49 тыс. м² малоэтажного жилья.

В настоящее время определено 57 перспективных земельных участков, находящихся в муниципальной и не разграниченной государственной собственности, расположенных в наиболее востребованных городах и районах республики, которые могут быть вовлечены в оборот в целях жилищного строительства в 2013-2015 гг.

Данные территории включены в Региональный адресный перечень земельных участков для жилищного строительства и комплексного освоения в целях жилищного строительства, который утверждается постановлением Правительства Республики Дагестан.

\title{
Библиографический список:
}

1. Постановление Правительства РД от 28 августа 2013 г. №413

2. Постановление Правительства РД от 30.07.2012 г. №276

УДК 339.13.017

\section{ББК 65.31}

Дуллуева Р.М., Исалова М.Н.

ОСНОВНЫЕ ЗАДАЧИ ЭФФЕКТИВНОГО УПРАВЛЕНИЯ ПОВЕДЕНИЕМ СУБЪЕКТОВ НА РЫНКЕ НЕДВИЖИМОСТИ

\author{
Dullueva R.M., Isalova M.N.
}

\section{PRIMARY TASK OF EFFICIENT MANAGEMENT BEHAVIOUR SUBJECT ON MARKET OF PREMISES}

В работе рассматриваются основные проблемы формирования модельного принципа организации управления поведением различных субъектов на рынке недвижимости. Предлагается использовать лингвистические переменные для обобщенного представления различных сегментов рынка и построения информачионно-аналитической модели принятия эффективных управленческих решений.

Ключевые слова: рынок недвижимости, сегментирование рынка, субъекты рынка, управление поведением, нечеткая шкала представления данных.

In work are considered main problems of the shaping the model principle to organizations of behavior management different subject on the market of the premises. It is offered use linguistically variable for generalized presentations different segment market and buildings information-analytical model of the taking the efficient man- 